\title{
OPEN ACCESS CULTURE AND ACCEPTANCE OF OPEN EDUCATIONAL RESOURCES IN CROATIAN PUBLIC UNIVERSITIES ${ }^{2}$
}

\begin{abstract}
The purpose of this paper is to contribute to the understanding of the open access culture and its impact on the use of Open Educational Resources (OER). There are many examples of using the term "open access culture", but without giving an explicit description of it. The aim of this research is to offer conceptualization of the open access culture, identify its main components, and determine the impact of this variable on the intention to use and the actual use of Open Educational Resources by the members of public higher education institutions in Croatia. The sample consisted of 427 respondents. Keeping in mind that culture has a significant impact on the behaviour of an individual, but it also manifests itself through this behaviour, the research model will be proposed. The variable "open access culture" will be observed on a personal, professional and organizational level and it will include attitudes, perception, norms and politics towards open access to scientific and educational content and knowledge sharing. For the purpose of this study a questionnaire was prepared. Each part of the variable "open access culture", as well as the intention to use and the actual use of OER, has been tested using a set of statements with answers on a 5-degree Likert type scale. The respondents have expressed a moderate open access culture. The actual use of OER, as well as the intention to use OER, is also in the middle of measurement scale. In order to achieve the aim of this research, three main hypotheses have been proposed. The results of multiple regression analysis show that the proposed model with predictor variable "open access culture" has a significant prognostic value on the intention to use and the actual use of OER, with a stronger influence on the intention to use OER. Considering the individual influence of the components of the predictor variable, the open access culture at professional level has the strongest influence on the intention to use and the actual use of OER.
\end{abstract}

Keyword: open access, open educational resources, open access culture, OER acceptance

\section{INTRODUCTION}

The problem area of the paper is the acceptance of Open Educational Resources while the aim of the research is to examine whether and to what extent the open access culture affects the actual use and the intention to use Open Educational Resources. The paper focuses on the influence of one aspect of culture as a determinant of human behaviour, knowing that culture and technology are interrelated - culture creates and shapes technology, but technology changes culture as well.

PhD, Senior Lecturer, Polytechnic of Rijeka, Vukovarska 58, 51000 Rijeka, Croatia. E-mail:elena@veleri.hr

2 Received: 11 January 2018; Accepted: 1 March 2018 
UNESCO defines Open Educational Resources (OER) as "the open provision of educational resources, enabled by information and communication technologies, for consultation, use and adoption by a community of users for non-commercial purposes" (Camilleri et al, 2014). The Hewlett Foundation, an organization that has significantly contributed to the development of Open Educational Resources, considers that "the OER are teaching, learning, and research resources that reside in the public domain or have been released under an intellectual property license that permits their free use or repurposing by others" (Camilleri et al, 2014). A similar definition was given by OECD-a defining them as "digitised materials offered freely and openly for educators, students and self-learners to use and reuse for teaching, learning and research" (Camilleri et al, 2014). OER include learning content (full courses, course materials and modules, textbooks, videos and other multimedia content, tests, quizzes, syllabuses etc.), software tools and licenses for using and distributing such resources like open licences (e.g. Creative Commons).

Open access to educational resources is a way to make education accessible to all who want to learn and to give teachers the opportunity to enrich their pedagogical practice (UNESCO, 2011). Although Open Educational Resources have been present since the launching of the MIT Open Course Ware (OCW) project and the release of the first Creative Commons licenses in 2002, and the emergence of the massive open online courses (MOOCs) in 2008, OER are still being viewed as a global innovation. Despite many advantages, the research has shown that OER is in the initial phase of acceptance (McKerlich et al, 2013; Allen, Seaman, 2014; Reed, 2012, Arcos et al, 2014). Many factors can foster the use of Open Educational Resources and contribute to OER becoming a modus operandi in higher education. It is of extreme importance to change the existing mindset and habits that shape the way of creating, sharing and (re)using educational resources and to support collaborative communities, adapt the rewarding and promotion systems in educational institutions, adopt and implement the Open Educational Resources Policy (Torres, 2012; Allen, Seaman, 2014; Arcos et al, 2014; McKerlich et al, 2013).

Culture can be described as a set of values and beliefs that shape behaviour. The behaviour of users towards an information system is determined by "values, mindset, status and user rules", namely by the culture that defines the place and role of that particular information system in society (Tuđman et al., 1993). Open Educational Resources imply the use of network technology and online information systems. Today's Web technology enables access, sharing and dissemination of knowledge in completely new ways, changing the processes of research, scientific communication, teaching and learning, and leads to the creation of a culture of openness (Torres, 2012).

The culture of openness includes attitudes towards Open Access, as well as towards the context in which researchers work and how this leads them to value (or not) the potential of Open Access (Swan, 2006). The open access culture embraces the idea that an open access to scientific and educational contents does not diminish their value, but instead it expands and improves them in unexpected ways (Peters, Roberts, 2012). It is considered that the open access culture brings new values such as ethics of sharing, participation and collaboration, and reliance in academic productivity as a social category (liyoshi, Kumar, 2008; Peters, Roberts, 2011; Torres, 2012). It changes the educational practice from formal academic teaching and learning to collaborative learning and exchanging of knowledge and engaging students in the learning process. The adoption of an Open 
Educational Resources policy brings significant changes in organizational culture, which results in the spreading of the open access culture (Torres, 2012). Embracing a culture of openness as a core value and an institutional strategy is the biggest challenge for higher educational institutions because the mindset of the majorities is set on the culture of "not open“ and these majorities prefer to maintain the status quo (Torres, 2013).

\section{METODOLOGY}

\section{1 Research model and hypotheses}

Keeping in mind that culture has a significant impact on the behaviour of an individual, but that it is also manifested through this behaviour, the influence of the variable open access culture on the intention to use and the actual use of Open Educational Resources will be explored, as shown in Figure 1. The Unified Theory of Acceptance and Use of Technology (UTAUT, Venkatesh et al., 2003) has been selected as the reference theoretical model of research. The UTAUT aims to observe the influence of 4 predictor variables (performance expectancy, effort expectancy, social influence, and facilitating conditions) on the behaviour intention and actual behaviour towards information technology or information system.

The proposed model observes the open access culture at three levels: personal, professional and organizational. The open access culture at the personal level refers to the awareness of and attitudes towards the Open Access movement, Open Educational Resources and knowledge sharing. Rolfe (2012) and Torres (2012) discuss the importance of raising awareness of the OER and Creative Commons licenses, understanding all the benefits they bring to teachers and students, and forming positive attitudes. Next, the open access culture at the professional level refers to respondents' perception of norms in research and teaching that foster open access in science and education and bring changes in teaching practice. Lastly, the open access culture at the organizational level refers to respondents' perception of organizational values towards open sharing of knowledge, as well as perception of institutional OA and OER policy, if there is any at all.

Figure 1. Research model

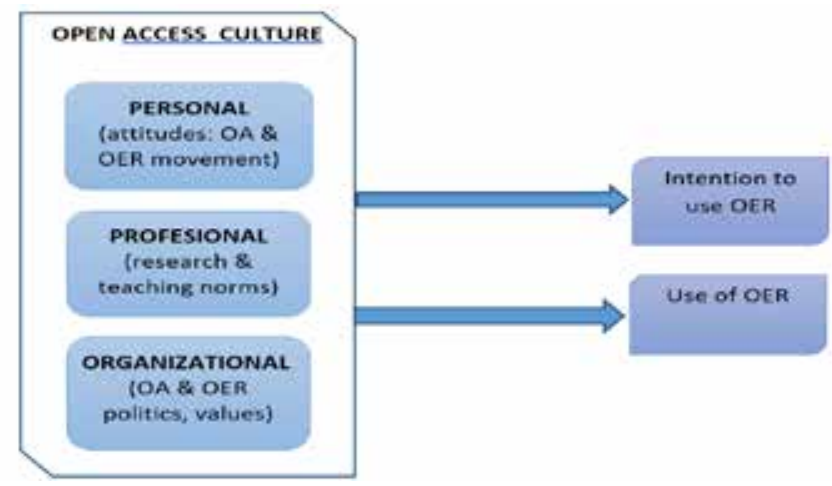

Source: Author 
Three main hypotheses were set based on the proposed research model. The first hypothesis $(\mathrm{H} 1)$ seeks to ascertain whether there is a positive and statistically significant correlation between open access culture and the intention to use Open Educational Resources or the actual use of Open Educational Resources. The second hypothesis $(\mathrm{H} 2)$ claims that open access culture has a significant and positive impact on the intention to use of Open Educational Resources and their actual use. The third hypothesis $(\mathrm{H} 3)$ argues that the combination of personal, professional and organizational levels of open access culture statistically significantly predicts the intent and the actual use of Open Educational Resources, that is, that the proposed research model is statistically significant. Descriptive statistics was used for qualitative analysis of the results while Pearson's correlation, linear and multiple regression analysis were utilized to test the hypotheses.

\subsection{The questionnaire}

A survey questionnaire was designed to suit the purpose of this research. The questionnaire consisted of 3 parts: general demographic questions, questions about open access culture (Table 2), and questions about the intention and actual use of OER (Table 3). At the beginning of the second part of the questionnaire, the description of Open Educational Resources was given, to avoid different interpretations. The survey questionnaires in the research by Rolfe (2012), McKerlich et al. (2013) and Kelly (2014) served as guidelines for the realisation of the variable open access culture. The questions for the variable open access culture (personal, professional and organizational levels), behavioural intention and the actual use of OER were tested with 5 items each. Respondents indicated the level of agreement with these statements on the 5-degree Likert type scale (" 1 " means strongly disagree and " 5 " strongly agree). As for the recommendations by Venkatesh et al. (2003), the question regarding the intention to behave included the exact time period in which such behaviour was expected. The questionnaire was tested in a pilot study on a sample of 34 respondents to determine the reliability of the measuring instrument (results of Cronbach's Alpha: $O A$ culture, personal, $\alpha=0.87 ; O A$ culture, professional, $\alpha=0.68$; $O A$ culture, organizational, $\alpha=0.86 ;$ OER intention, $\alpha=0.9 ;$ OER use, $\alpha=0.87$ ), and necessary corrections on variable $O A$ culture at professional level were made. The online survey questionnaire was created using the Lime Survey and distributed via e-mail. The survey was anonymous and participation in the research voluntary.

\subsection{The sample}

Research population consisted of people full-time employed at Croatian public universities, with academic titles or assistants. A stratified random sample was used, and 427 respondents fully completed the questionnaire. The research sample and population data are described in Table 1 (Državni zavod za statistiku - Croatian Bureau of Statistics, 2016). 
Table 1. Descriptive statistics of the sample

\begin{tabular}{|c|c|c|c|}
\hline \multicolumn{2}{|r|}{ Characteristics } & $\begin{array}{c}\text { Population } \\
(N=7647)\end{array}$ & Sample $(N=427)$ \\
\hline \multirow{7}{*}{ University name } & University of Zagreb & $56.57 \%$ & $47.78 \%$ \\
\hline & University of Rijeka & $11.97 \%$ & $12.88 \%$ \\
\hline & Josip Juraj Strossmayer University in Osijek & $11.91 \%$ & $11.71 \%$ \\
\hline & University of Split & $11.15 \%$ & $11.71 \%$ \\
\hline & University of Zadar & $4.81 \%$ & $8.43 \%$ \\
\hline & Juraj Dobrila University of Pula & $1.92 \%$ & $4.68 \%$ \\
\hline & University of Dubrovnik & $1.67 \%$ & $2.82 \%$ \\
\hline \multirow{5}{*}{ Academic titles } & Full professor & $22.39 \%$ & $20.00 \%$ \\
\hline & Associate professor & $16.18 \%$ & $18.12 \%$ \\
\hline & Assistant professor & $22.83 \%$ & $30.82 \%$ \\
\hline & Senior assistent & $14.65 \%$ & $15.06 \%$ \\
\hline & Assistent & $23.95 \%$ & $16.00 \%$ \\
\hline \multirow{2}{*}{ Gender } & Male & $50.23 \%$ & $48.01 \%$ \\
\hline & Female & $49.77 \%$ & $51.99 \%$ \\
\hline \multirow{7}{*}{ Scientific field } & Biomedicine and Health & $11.59 \%$ & $12.71 \%$ \\
\hline & Biotechnical science & $8.15 \%$ & $10.12 \%$ \\
\hline & Social science & $28.76 \%$ & $31.06 \%$ \\
\hline & Humanities & $9.44 \%$ & $11.06 \%$ \\
\hline & Natural science & $9.44 \%$ & $12.00 \%$ \\
\hline & Technical science & $23.18 \%$ & $22.35 \%$ \\
\hline & Arts & $9.44 \%$ & $0.71 \%$ \\
\hline
\end{tabular}

Source: Author

\section{RESULTS AND DISCUSSION}

The results show that respondents have expressed a moderate open access culture $(\bar{x}=3.57$; $\sigma=0.97$ on scale from 1 to 5 ). The best result was achieved for the open access culture at the professional level $(\bar{x}=3.84 ; \sigma=0.87)$. Most respondents agree that public universities should adopt OA and OER policies, they believe that teachers need to be actively involved in open sharing of knowledge. Further on they consider that retrieval of quality OER is an important activity, but that it does not link OER to Creative Commons licenses. When the open access culture at the personal level $(\bar{x}=3.68 ; \sigma=0.99)$ is being considered, the majority of the respondents expressed a positive attitude towards OER integration into the higher education, they believe that OER 
foster the educational practices, but estimate that they are not sufficiently informed about these issues. The lowest result was achieved by open access culture at the organizational level $(\bar{x}=3.09$; $\sigma=1.05$ ) as respondents believe that there is a lack of promotion of open access to scientific and educational contents and a lack of institutional strategies and policies of Open Access and Open Educational Resources.

Table 2. Descriptive statistics for "open access culture"

\begin{tabular}{|c|c|c|c|c|c|c|c|}
\hline \multirow[b]{2}{*}{ Open access culture statements } & \multicolumn{5}{|c|}{ Frequency (\%), N = 427} & \multirow[b]{2}{*}{$\begin{array}{l}\text { Arithmetic } \\
\text { mean }\end{array}$} & \multirow[b]{2}{*}{$\begin{array}{l}\text { Standard } \\
\text { deviation }\end{array}$} \\
\hline & 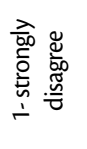 & 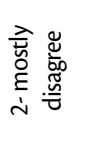 & 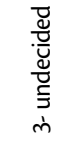 & 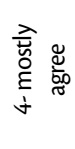 & 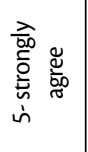 & & \\
\hline \multicolumn{6}{|l|}{ OA culture, personal level } & 3.68 & 0.99 \\
\hline $\begin{array}{l}\text { I believe that integrating open } \\
\text { educational resources into the higher } \\
\text { education system is a good idea. }\end{array}$ & 1.64 & 1.41 & 13.15 & 52.11 & 31.69 & 4.11 & 0.80 \\
\hline $\begin{array}{l}\text { I am aware of the initiatives of Open } \\
\text { Access and Open Educational } \\
\text { Resources. }\end{array}$ & 9.86 & 15.49 & 35.92 & 29.58 & 9.15 & 3.13 & 1.10 \\
\hline $\begin{array}{l}\text { I believe that Creative Commons } \\
\text { licenses are an important part of } \\
\text { open educational resources. }\end{array}$ & 3.29 & 1.41 & 55.40 & 22.07 & 17.84 & 3.50 & 0.91 \\
\hline $\begin{array}{l}\text { I believe that open access to scientific } \\
\text { and educational resources improves } \\
\text { educational practice. }\end{array}$ & 1.41 & 2.11 & 20.19 & 51.88 & 24.41 & 3.96 & 0.81 \\
\hline \multicolumn{6}{|l|}{ OA culture, professional level } & 3.84 & 0.87 \\
\hline $\begin{array}{l}\text { Finding quality open educational } \\
\text { resources should be the responsibility } \\
\text { of each teacher. }\end{array}$ & 1.88 & 7.04 & 22.54 & 49.06 & 19.48 & 3.77 & 0.91 \\
\hline $\begin{array}{l}\text { Teachers should actively participate } \\
\text { in the open sharing of knowledge and } \\
\text { educational resources. }\end{array}$ & 1.64 & 3.29 & 19.25 & 53.99 & 21.83 & 3.91 & 0.83 \\
\hline $\begin{array}{l}\text { It is desirable for teachers to use } \\
\text { the Creative Commons licenses for } \\
\text { teaching materials they publish on } \\
\text { the Internet. }\end{array}$ & 1.88 & 2.35 & 54.46 & 24.65 & 16.67 & 3.52 & 0.86 \\
\hline $\begin{array}{l}\text { I consider it important that the } \\
\text { Croatian higher education institutions } \\
\text { adopt OA and OER policies. }\end{array}$ & 1.17 & 3.29 & 15.02 & 38.50 & 42.02 & 4.17 & 0.88 \\
\hline \multicolumn{6}{|l|}{ OA culture, organizational level } & 3.09 & 1.05 \\
\hline $\begin{array}{l}\text { The institution where I am employed } \\
\text { is flexible and open to new ideas. }\end{array}$ & 6.34 & 15.96 & 30.05 & 35.92 & 11.74 & 3.31 & 1.07 \\
\hline
\end{tabular}




\begin{tabular}{|c|c|c|c|c|c|c|c|}
\hline \multirow[b]{2}{*}{ Open access culture statements } & \multicolumn{5}{|c|}{ Frequency (\%), N = 427} & \multirow[b]{2}{*}{$\begin{array}{l}\text { Arithmetic } \\
\text { mean }\end{array}$} & \multirow[b]{2}{*}{$\begin{array}{l}\text { Standard } \\
\text { deviation }\end{array}$} \\
\hline & 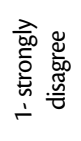 & 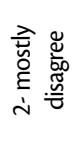 & 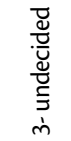 & 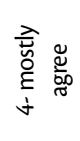 & 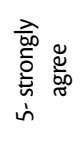 & & \\
\hline \multicolumn{6}{|l|}{ OA culture, personal level } & 3.68 & 0.99 \\
\hline $\begin{array}{l}\text { I believe that integrating open } \\
\text { educational resources into the higher } \\
\text { education system is a good idea. }\end{array}$ & 1.64 & 1.41 & 13.15 & 52.11 & 31.69 & 4.11 & 0.80 \\
\hline $\begin{array}{l}\text { I am aware of the initiatives of Open } \\
\text { Access and Open Educational } \\
\text { Resources. }\end{array}$ & 9.86 & 15.49 & 35.92 & 29.58 & 9.15 & 3.13 & 1.10 \\
\hline $\begin{array}{l}\text { The management of the institution } \\
\text { where l am employed is trying hard to } \\
\text { develop an open knowledge sharing } \\
\text { culture. }\end{array}$ & 7.51 & 18.08 & 36.62 & 28.40 & 9.39 & 3.15 & 1.06 \\
\hline $\begin{array}{l}\text { The institution where I am employed } \\
\text { contributes to the popularization } \\
\text { of open access to scientific and } \\
\text { educational resources. }\end{array}$ & 7.51 & 16.67 & 41.31 & 24.88 & 9.62 & 3.13 & 1.04 \\
\hline $\begin{array}{l}\text { The institution where I am employed } \\
\text { has adopted OA or OER policies. }\end{array}$ & 12.68 & 18.51 & 51.41 & 13.38 & 3.99 & 2.78 & 0.98 \\
\hline
\end{tabular}

Source: Author

The respondents expressed moderate intention to use Open Educational Resources in the next year $(\bar{x}=3.34 ; \sigma=0.93)$. Most of them expressed their readiness to find a quality OER within their teaching subject while they had the least intention to use Creative Commons licenses for some of their teaching materials and make them openly available. The actual use of Open Educational Resources was lower, but also moderate $(\bar{x}=3.11 ; \sigma=1.14)$. The most frequent purpose of using OER by the respondents was for their own professional development. They rarely used OER in their teaching and rarely shared experiences with OER.

Table 3. Descriptive statistics for the intention and the actual use of OER

\begin{tabular}{|c|c|c|c|c|c|c|c|}
\hline \multirow[b]{2}{*}{ OER acceptance statements } & \multicolumn{5}{|c|}{ Frequency (\%), N = 427} & \multirow[b]{2}{*}{$\begin{array}{c}\text { Arithmetic } \\
\text { mean }\end{array}$} & \multirow[b]{2}{*}{$\begin{array}{l}\text { Standard } \\
\text { deviation }\end{array}$} \\
\hline & 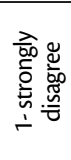 & 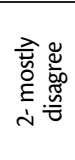 & 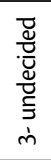 & 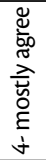 & 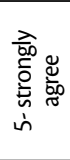 & & \\
\hline \multicolumn{6}{|l|}{ Intention to use OER } & 3,34 & 0,93 \\
\hline
\end{tabular}




\begin{tabular}{|l|l|l|l|l|l|l|l|}
\hline $\begin{array}{l}\text { By the beginning of the next academic } \\
\text { year I intend to find several quality } \\
\text { open educational resources in my field } \\
\text { of interest. }\end{array}$ & 4,46 & 8,45 & 35,92 & 42,25 & 8,92 & 3,42 & 0,926 \\
\hline $\begin{array}{l}\text { In the next year I intend to adjust the } \\
\text { selected open educational resources to } \\
\text { the needs of teaching that I perform. }\end{array}$ & 4,46 & 8,92 & 40,61 & 37,56 & 8,45 & 3,36 & 0,919 \\
\hline $\begin{array}{l}\text { In the next year I intend to include } \\
\text { open educational resources in the } \\
\text { teaching that I perform. }\end{array}$ & 4,46 & 8,22 & 42,25 & 37,32 & 7,75 & 3,35 & 0,902 \\
\hline $\begin{array}{l}\text { I intend to engage or continue to } \\
\text { participate in online discussions in my } \\
\text { scientific field and contribute to open } \\
\text { sharing of knowledge. }\end{array}$ & 5,63 & 9,39 & 31,92 & 37,56 & 15,49 & 3,48 & 1,042 \\
\hline $\begin{array}{l}\text { In the next year I intend to make } \\
\text { some of my teaching materials openly } \\
\text { available under the Creative Commons } \\
\text { license. }\end{array}$ & 7,51 & 11,03 & 54,46 & 20,19 & 6,81 & 3,08 & 0,940 \\
\hline Use of OER & 12,44 & 25,82 & 32,63 & 16,90 & 12,21 & 2,90 & 1,183 \\
\hline $\begin{array}{l}\text { I use open educational resources for } \\
\text { my own training. }\end{array}$ & 4,46 & 11,74 & 40,61 & 27,23 & 15,96 & 3,38 & 1,028 \\
\hline $\begin{array}{l}\text { When teaching I use open educational } \\
\text { resources in their original form. }\end{array}$ & 14,55 & 22,77 & 40,14 & 16,20 & 6,34 & 2,77 & 1,085 \\
\hline $\begin{array}{l}\text { I tailor selected open educational } \\
\text { content to suit students and teaching } \\
\text { needs. }\end{array}$ & 9,15 & 15,73 & 39,91 & 23,71 & 11,50 & 3,12 & 1,096 \\
\hline $\begin{array}{l}\text { I openly share my teaching materials } \\
\text { and other educational resources. }\end{array}$ & 7,75 & 14,55 & 29,81 & 28,40 & 19,48 & 3,37 & 1,175 \\
\hline $\begin{array}{l}\text { I publicly share the experience of using } \\
\text { open educational resources in teaching } \\
\text { and discuss the possibilities of their } \\
\text { improvement. }\end{array}$ & & & & & & & \\
\hline
\end{tabular}

Source: Author

These results are similar with the results of the study conducted on a sample of 2,144 faculties in the United States which showed that faculty members understood the OER differently (what it was and was not), they often failed to link Creative Commons licensing with OER and reported the use of OER at a very low level in teaching (Allen, Seaman, 2014).

A positive and statistically significant correlation between open access culture and the intention to use OER based on Pearson's correlation $(r=0.621 ; p<0.01)$ and between open access culture and the actual use of $O E R(r=0.514 ; p<0.05)$ was confirmed. Therefore, the first hypothesis was accepted. This correlation was stronger for the actual use of OER. 
To determine if there was a causal connection between these two variables, the second hypothesis was tested by linear regression analysis. A statistically significant, strong and positive influence of predictor variable open access culture on dependant variable intention to use OER ( $\mathrm{t}=16.309 ; \mathrm{p}<0.01)$ was confirmed. With the increase of open access culture by 1 point on the scale, the intention to use OER would increase on average by $88 \%$. Furthermore, a statistically significant and positive influence of predictor variable open access culture on dependant variable actual use of OER $(t=12.373 ; p<0.01)$ was also confirmed. With the increase of open access culture by 1 point on the scale, the actual use of OER would increase on average by $77 \%$. The second hypothesis was accepted in its entirety.

The results of the multiple regression analysis showed that the proposed combination of all three components of the variable open access culture (personal, professional and organizational levels) significantly predicted the dependent variables intention to use OER $(R=0.684 ; F=123.136 ; p<0.01)$ and actual use of $O E R(R=0.545 ; F=59.177 ; p<0.01)$. Therefore, the third hypothesis was accepted as well as the proposed research model. Taken individually, the most important component in the observed model was the open access culture at the professional level as it had the greatest influence on the intention to use OER and the actual use of OER.

\section{CONCLUSION}

Open Educational Resources are important for society as a whole, because they make it possible for every individual to enjoy their right to education and to free access to quality educational resources. Despite many advantages, the results of the recent research have indicated that OER have not yet become an integral part of educational practice. The reason for this may lie in the fact that a shift from traditional teaching and learning is needed, as well as a new view on creation, sharing, re-use and adaptation of teaching materials.

This research has confirmed that the actual use of OER in Croatian public higher education institutions is moderate, however with optimistic findings that the respondents expressed a readiness to use OER in the near future. The research has confirmed that the proposed conceptual model with the variable open access culture has significant prognostic value on the intention to use and the actual use OER. The independent variable open access culture achieved better prognostic value on the intention to use OER. The highest prognostic value on the intention to use and the actual use OER was achieved by the professional level of open access culture, which means that professional norms play a very important role in the acceptance of OER. Furthermore, it is important to inform members of the academic community about the idea of open access, OER and Creative Commons licenses, and to develop positive attitudes accordingly (open access culture at the personal level). The lowest prognostic value was achieved by the organizational level of open access culture because there is a lack of OA and OER policies and promotional activities in HE institutions. The limitation of this paper is that there is no similar research dealing with open access culture, with which to compare the results. Torres (2012; 2013) and Peters, Roberts (2012) speak 
about the important role of open access culture, but they have not empirically proven the thesis.

It can be concluded that, in order to further increase the use of Open Educational Resources, it is not enough to develop infrastructure, choose technology and offer content, but it is necessary to change the mindset, i.e. the open access culture at a personal, professional and organizational level.

\section{REFERENCES}

Allen, I. E., Seaman, J. (2014) Opening the Curriculum: Open Educational Resources in U.S. Higher Education, BABSON Survey Research Group, http://www.onlinelearningsurvey.com/reports/openingthecurriculum2014.pdf (22. 12. 2017.)

Arcos, B., Farrow, R., Perryman, L. A., Pitt, R. \& Weller, M. (2014) OER Evidence Report 2013-2014, OER Research Hub, http://oerresearchhub.org/about-2/reports/ (20. 12. 2017.)

Camilleri, A. F., Ehlers, U. D., Pawlowski, J. (2014), State of the Art Review of Quality Issues related to Open Educational Resources (OER), European Commission Joint Research Centre, Institute for Prospective Technological Studies, doi: $10.2791 / 80171$

Državni zavod za statistiku (2016), Visoko obrazovanje u 2015., Statistička izvješća, Zagreb, https://www.dzs.hr/ (18. 12. 2017.)

liyoshi, T., Kumar, M. S. (2008) Opening Up Education: The Collective Advancement of Education through Open Technology, Open Content, and Open Knowledge, The MIT Press, Cambridge

Kelly, H. (2014) A Path Analysis of Educator Perceptions of Open Educational Resources Using Technology Acceptance Model, The International Review of Research in Open and Distance LEarning, Vol. 15, No. 2., p. $26-42$

McKerlich, R., Ives, C., McGreal, R., (2013) Measuring Use and Creation of Open Educational Resources in Higher Education, The International Review of Research in Open and Distance Learning, Vol. 14, No. 4.

Peters, M. A., Roberts, P. (2012) The Virtues of Openness: Education, Science, and Scholarship in the Digital Age, Paradigm Publisher, London

Reed, P. (2012) Awareness, attitudes and participation of teaching staff towards the open content movement in one university, Research in Learning Technology, Vol. 20, http://www.tandfonline.com/doi/full/10.3402/rlt.v20i0.18520 (18. 12. 2017.)

Rolfe, V. (2012) Open educational resources: staff attitudes and awareness, Research in Learning Technology, Vol. 20, http://www.researchinlearningtechnology.net/index.php/rlt/article/view/14395 (4. 12. 2017.)

Swan, A. (2006), The culture of Open Access: researchers' views and responses, in Jacobs, N., Open Access: Key Strategic, Technical and Economic Aspects, Chapter 7, Chandos, Oxford, p. 52-59, http://eprints.ecs.soton.ac.uk/12428/01/ asj7.pdf_ (20. 12. 2017.)

Torres N. P. M. (2012) Towards a culture of openness: Raising awareness and enabling policies in Latin American Higher Education, http://ess.iesalc.unesco.org.ve/index.php/ess/article/download/414/351

Torres, N. P. M. (2013) Embracing openness: The challenges of OER in Latin American education, Open Praxis, Vol. 5., No. 1, p. 81-89, DOl:10.5944/openpraxis.5.1.33

Tuđman, M., Boras, D., Dovedan, Z. (1993) Uvod u informacijsku znanost, Školska knjiga, Zagreb

UNESCO (2011) Guidelines on Open Educational Resources in Higher Education, http://unesdoc.unesco.org/ images/0021/002136/213605e.pdf (22. 12. 2017.) 
E. Krelja Kurelovic: Open Acces Culture and Acceptance of Open Educational Resources in Croatian... Zbornik Veleučilišta u Rijeci, Vol. 6 (2018), No. 1, pp. 39-50

Venkatesh, V., Morris, M. G., Davis, G. D., Davis, F. D. (2003) User Acceptance of Information Technology: Toward a Unified View, MIS Quarterly, Vol. 27, No. 3, pp. 425-478, https://csdl-techreports.googlecode.com/svn/trunk/ techreports/2005/05-06/doc/Venkatesh2003.pdf (20.12. 2017.) 


\section{KULTURA OTVORENOG PRISTUPA I PRIHVAĆANJE OTVORENIH OBRAZOVNIH SADRŽAJA NA HRVATSKIM JAVNIM SVEUČILIŠTIMA}

\section{SAŽETAK}

Surha rada je pridonijeti razumijevanju kulture otvorenog pristupa i njenog utjecaja na korištenje otvorenih obrazounih sadržaja (OER). Postoje mnogi primjeri upotrebe pojma "kultura otvorenog pristupa", ali bez eksplicitnog objašnjenja što se pod time podrazumijeva. Cilj ovog rada je rasvijetliti tumačenje kulture otvorenog pristupa, identificirati njene glavne komponente i odrediti utjecaj ove varijable na namjeru ponašanja i stvarnu uporabu otvorenih obrazovnih sadržaja kod članova visokoškolskih institucija. Uzorak su činila 427 ispitanika. Imajući na umu da kultura ima značajan utjecaj na ponašanje pojedinca, ali se manifestira kroz to ponašanje, predložen je model istraživanja u kojem se testira utjecaj kulture otvorenog pristupa na namjeru korištenja i stvarno korištenje otvorenih obrazovnih sadržaja. Varijabla "kultura otvorenog pristupa" promatra se na osobnoj, profesionalnoj i organizacijskoj razini, a uključuje stavove, percepciju, norme i politiku prema otvorenom pristupu znanstvenim i obrazovnim sadržajima i razmjeni znanja. Anketni upitnik izrađen je za potrebe ovog istraživanja. Svaki dio varijable "kultura otvorenog pristupa" testiran je pitanjima kojima su ispitanici izrazili svoju razinu slaganja na ljestvici Likertovog tipa. Ispitanici su iskazali umjerenu kulturu otvorenog pristupa, a namjera i stvarna uporaba OER-a je također u sredini ljestvice mjerenja. U skladu s ciljem istraživanja predložene su tri glavne hipoteze. Rezultati višestruke regresijske analize pokazuju da predloženi istraživački model s prediktorskom varijablom "kultura otvorenog pristupa" ima značajnu prognostičku vrijednost za namjeru i stvarnu uporabu OER-a, a jači utjecaj prediktorska varijabla ima na namjeru korištenja OER-a. Gledajući pojedinačni utjecaj komponenti prediktorske varijable, kultura otvorenog pristupa na profesionalnoj razini ima najveći utjecaj na namjeru i stvarnu uporabu OER-a.

Ključne riječi: otvoreni pristup, otvoreni obrazovni sadržaji, kultura otvorenog pristupa, prihvaćanje OER-a

Dr. sc., v. pred., Veleučilište u Rijeci, Vukovarska 58, 51000 Rijeka, Hrvatska.E-mail: elena@veleri.hr

Datum primitka rada: 11. 1. 2018.; datum prihvaćanja rada: 1. 3. 2018. 